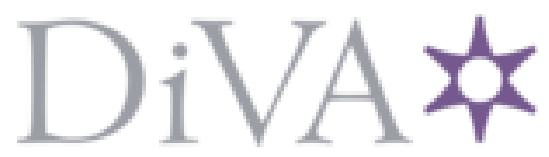

http://www.diva-portal.org

\title{
Preprint
}

This is the submitted version of a paper published in Journal of small business management (Print).

Citation for the original published paper (version of record):

Chirico, F., Salvato, C., Byrne, B., Akhter, N., Arriaga Múzquiz, J. (2016)

Commitment escalation to a failing family business.

Journal of small business management (Print)

Access to the published version may require subscription.

N.B. When citing this work, cite the original published paper.

Permanent link to this version:

http://urn.kb.se/resolve?urn=urn:nbn:se:hj:diva-28154 


\author{
Commitment Escalation to a Failing Family Business \\ Francesco Chirico* \\ Jönköping International Business School \\ Center for Family Enterprise and Ownership - CeFEO \\ PO Box 1026 \\ SE-551 11 Jönköping, Sweden \\ EGADE Business School, Tecnológico de Monterrey \\ Tel. +46 (0)361018 32 \\ Fax. +46 (0)36160070 \\ Francesco.Chirico@jibs.hj.se \\ Carlo Salvato \\ Bocconi University \\ Department of Management \& Technology \\ Via Rontgen 1 - 20136 Milan (Italy) \\ Tel.: +39 02 58362535/34 \\ Barbara M. Byrne \\ School of Psychology \\ University of Ottawa \\ 136 Jean Jacques Lussier, Vanier Hall \\ Ottawa, Ontario, Canada K1N 6N5 \\ Naveed Akhter \\ Jönköping International Business School \\ Center for Family Enterprise and Ownership - CeFEO \\ PO Box 1026 \\ SE-551 11 Jönköping, Sweden \\ Juan Arriaga Múzquiz \\ EGADE Business School \\ Tecnológico de Monterrey \\ Ave. Eugenio Garza Sada 2501 Sur Col. Tecnológico \\ C.P. 64849 Monterrey, Nuevo León, México
}

Keywords: family business, commitment entrapment, resistance to change

*Corresponding author 


\section{Commitment Escalation to a Failing Family Business}

The overarching intent of this manuscript is to heighten awareness to the concept of commitment escalation as it bears on a failing family business. Specifically, drawing on the concept of emotional ownership, together with self-justification arguments, we a) identify factors considered to be most forceful in contributing to the presence of commitment escalation and thus, resistance to change in a failing family business (i.e., emotional ownership, feeling of responsibility, investment of capital, temporal distance from the founder's business, individualism/collectivism), and b) model these related factors in a form that can serve heuristically to stimulate future empirical research capable of testing for the construct validity of commitment escalation in a family business context. We present potential items that may be useful for future scholars in measuring our constructs of interest as they relate to a failing family business.

\section{INTRODUCTION}

The family business has been defined as an organization in which both the ownership and management are concentrated within a family unit, with family members striving to maintain intra-organizational family-based relatedness (Arregle, Hitt, Sirmon \& Very, 2007). More specifically, the family business is characterized by ownership identity, long-term orientation, strong family values, high-level commitment, and a desire to keep the original founder's business formula unchanged over time (Arregle et al., 2007; Nicholson, 2008; Zahra, 2005). In light of this highly revered value of stability and continuity for the founder's business, it is not surprising that a review of the family business literature reveals most research to focus on aspects of this continuity factor with explanation being rooted in "emotional ownership". That is, the strong emotional commitment and high identification of family members to the business (Björnberg \& Nicholson, 2012, p. 374).

Over this past decade, however, scholars have begun to question the extent to which such stability and persistence toward the unchanged original founder's business formula is appropriate and wise (Salvato, Chirico, \& Sharma, 2010). This uncertainty is particularly relevant in failing situations such as the family business being no longer profitable due to huge decreasing revenues 
or increasing expenses, thereby ultimately leading to its insolvency (see e.g., Altman, 1968; Kaye, 1996, 1998). This reverse expectation of the family business addresses the issue of resistance to change. Change is a critically important decision for any business enterprise and is often regarded as a necessary prerequisite to competitive advantage (Duhaime \& Schwenk, 1985; Eisenhardt \& Martin, 2000; Yuen \& Hamilton, 1993). Van de Ven and Poole (1995, p. 512) defined change as, “one type of event, an empirical observation of difference in form, quality, or state over time in an organizational entity. The entity may be ... an organizational strategy, a program, a product, or the overall organization”.

Although change is often difficult to accept and implement, it is particularly so for the family business wherein emotional attachment (as family members) and rational judgment (as business managers) overlap, thereby significantly impacting strategic decision-making processes and behaviors (Olson, Zuiker, Danes, Stafford, Heck, \& Duncan, 2003). Researchers have noted that even in troubled economic times, and despite strong evidence in support of change, family members tend to make necessary personal sacrifices in order to keep the business running, thereby maintaining the status quo (Haynes, Walker, Rowe, \& Hong, 1999; Rosenblatt, 1991; Salvato et al., 2010). Such behavior often leads to path dependency in which "routines that worked well in the past are used again and again regardless of the strategic challenges facing the family firm” (Zahra, 2005, p. 24). For example, Gómez-Mejía, Haynes, Nunez-Nickel, Jacobson and Moyano-Fuentes (2007) found that because family businesses are concerned not only with financial returns, but also with non-financial goals, its owners and managers tend to act conservatively thereby avoiding strategic decisions that harm their family control in the business or may increase unexpected outcomes. 
This persistence to stay the course of the family business regardless of its impending failure, ultimately leads to an aura of commitment escalation (or entrapment) that prevents any form of change in, for instance, the strategy, the product, or the entire business activity (Brockner, Rubin \& Lang, 1981; Salvato et al., 2010). Given the potentially damaging effects of commitment escalation on a failing family business, both financially and personally, it is rather remarkable that to date, only a modicum of research has addressed the perspective of entrapment pertinent to the family business (De Tienne \& Chirico, 2013; Salvato et al., 2010; Sharma, \& Manikutti, 2005; Woods, Dalziel \& Barton, 2012). In particular, this research suggests that commitment escalation is likely to be highly relevant to the family firm context due to family members' emotional attachment and identification with the firm.

The intent of this manuscript, in broad terms, is to address this void in the literature by exploring the concept of commitment escalation as it bears on a failing family business. More specifically, the purposes are twofold: a) drawing on the concept of emotional ownership in combination with the theory of self-justification, to elucidate the extent to which the factors of emotional ownership, feeling of responsibility, investment of capital, and temporal distance from the founder's business contribute to the presence of commitment escalation and thus, resistance to change in a failing family business, and b) to model these factors in a form that can serve, heuristically, to stimulate future empirical research capable of testing for the construct validity of commitment escalation within a family business context. Our proposed conceptual model of commitment escalation to a failing family business is schematically portrayed in Figure 1. In addition, in Table 1 we present potential items that may be useful to other scholars to measure our constructs of interest in samples of failing family businesses.

- Insert Figure 1 about here - 


\section{THEORETICAL FRAMEWORK}

\section{Commitment Escalation}

Core skills instrumental in the past success of a business enterprise can contribute concomitantly to a state of rigidity that impacts its ability to adapt to future changing environments (Miller, 1990). When this happens, organizations are said to become "trapped” in their own business entities (Brockner \& Rubin, 1985; Schulz-Hardt, Thurow-Kröning, \& Frey, 2009) as their inability to adapt can inhibit any notion of change in terms of an organizational strategy, program, product, or the organization as a whole (Van de Ven \& Poole, 1995). It has frequently been noted that even in light of a failing course of action, decision-makers are often reluctant to de-commit and support change initiatives (Staw, 1976; 1981). Rather, they act as if they are locked in a failing action, with no recognition of the need to re-orient the business around a new strategy, program, product or, at worst, to exit the business altogether (Sleesman, Conlon, McNamara, \& Miles, 2012).

The topic of commitment has been explored extensively. The most frequently adopted definition is that coined by Staw, Brockner and colleagues (Staw 1976, 1981; Brockner, et al., 1986), where commitment is depicted as a psychological state that binds an individual to a particular course of action or line of behavior. Further, Meyer and colleagues (Meyer and Allen, 1991; Meyer and Herscovitch, 2001, p. 301) built on these studies to note that "[a]ll of the definitions of commitment in general make reference to the fact that commitment (a) is a stabilizing or obliging force, that (b) gives direction to behavior”. In the present study, the failing family business constitutes the entity to which family members are committed, whereas emotional ownership, along with the feeling of responsibility and investment of capital, identify the main underling motives that produce family members' commitment to their business. 
However, although most studies have been based on the assumption that high levels of commitment are good, others have revealed the possible dangers of high levels of commitment (e.g. Staw, 1981). Some findings suggest that high commitment may be linked to a lack of creativity and ineffective use of resources, both of which result in resistance to change (e.g. Brockner, Shaw \& Rubin, 1979; Staw, 1981, 1997). In addition, high commitment can lead individuals to behave in ways that might seem contrary to their own self-interests. This paradoxical situation led Randall (1987) to suggest that commitment has two faces. The first is a motivating face, which helps to overcome obstacles and achieve seemingly impossible goals. The second face of commitment is a wasteful one in which commitment evolves into entrapment such that resources are thrown after bad in attempts to accomplish impossible goals. The present paper seeks to explore the latter as it bears on resistance to change (Brockner et al., 1981; Brockner \& Rubin, 1985; Lopes, 1987; Staw, 1981).

The concept of commitment escalation (see Brockner et al., 1981, 1986; Schulz-Hardt et al., 2009; Sleesman et al., 2012; Staw, 1981; 1997) has been used largely to explain individuals’ tendency to attach psychological importance to their own behavior. It is defined as an increased commitment of individuals to an ineffective course of action that extends beyond an economically rational point, despite the presence of negative feedback concerning the viability of that course of action (see e.g. Brockner et al., 1986; Sleesman et al., 2012). In this situation, it is difficult to implement any form of change and time of persistence is therefore often used to operationalize these constructs (Schulz-Hardt et al., 2009). Long term investment is a key feature of commitment escalation, with the length of time changing the nature of risk, making it more likely as the company continues to pour resources into a failing course of action (Drummond, 2001). Indeed, the key danger of commitment escalation is that members of the firm can become 
so entrapped in a particular course of action, that any means of escape become increasingly more difficult and eventually impossible to execute. Such inaction will ultimately lead to a waste of resources (Wilson and Zhang, 1997).

Self-justification theory has been used widely in explaining the escalating behaviors of managers to "convince themselves that things do not look so bad” (Brockner, 1992, p. 54; Staw, 1997). Self-justification theory posits that individuals tend to escalate their commitment to a course of action in order to self-justify prior behavior (Staw \& Fox 1977; Whyte, 1986), which serves in proving to themselves (self-justification) and to others (external justification) that they are not only competent, but more importantly (in their view) 'correct'. Central to the concepts of self- and external justification are the notions of feeling of responsibility and investment of capital. That is, the sense that one is personally responsible for a failing course of action and has invested a large amount of resources, thereby leading to strong justifications about the decision taken (see Brockner, 1992; Staw, 1981; Whyte 1986; Whyte, 1993).

Some scholars (e.g. Bazerman, Tenbrunsel, \& Wade-Benzoni, 1998; Sleesman et al., 2012; Walsh, 1995), however, suggest that examination of emotions is essential to advancing our understanding of commitment escalation in failing situations. Such an emotion-based framework should be modeled within the framework of contexts in which positive and negative affects coexist and co-determine emotional commitment-related outcomes. One such context is offered by the family business in which emotional judgments and non-economic principles play large roles in the decision-making process (Björnberg \& Nicholson, 2012; Gómez-Mejía et al., 2007; Gómez-Mejía, Makri \& Larraza-Kintana, 2010). As we detail later, due to emotional reasons and the related extended time horizon of family firms (James, 1999; Zellweger, 2007), we claim that family members' escalation of commitment to their failing family business is a likely event. 


\section{Family Businesses and Emotional Ownership}

Family businesses, firms in which a family possesses a significant ownership stake and in whose operations multiple family members are involved (Arregle et al., 2007; Chirico \& Bau, 2014), are depicted as commitment-intensive organizations as family members manifest a strong sense of emotional attachment to, and identification with the business enterprise (Björnberg \& Nicholson, 2012; Gómez-Mejía et al., 2007). In a recent study of the relation/bond between individuals and the family firm, Björnberg and Nicholson (2012) perceived emotional ownership as the family members' sense of ownership to the business that derives from a sense of belongingness (i.e. identification) and attachment "beyond the monetary significance of the ownership bond” (p. 381). As such, emotional ownership may well explain why family businesses behave so distinctively (see also Astrachan and Jaskiewicz, 2008; Björnberg \& Nicholson, 2012; Zellweger \& Astrachan, 2008).

Interestingly, Björnberg and Nicholson (2012) view the emotional ownership “concept as a not-so-distant cousin to related constructs [such as social identification (Ashforth \& Mael, 1989), psychological ownership (Pierce, Kostova, \& Dirks, 2001) and affective organizational commitment (Meyer \& Allen, 1991)], but with enough differentiating features for it not to be a redundant neologism.” (p. 381) For instance, a central aspect of affective commitment is the emotional attachment and identification of employees to the organization which are mainly an outcome of their work experiences. Additionally, core to commitment is the desire/intention to remain affiliated with the business. The concept of emotional ownership instead describes the bond between family members and the family firm which goes beyond the only work experience in the family firm and may exist even without affiliation. 
Research shows that emotional attachment and judgment are highly entangled within the context of the family firm , thereby significantly influencing family members’ decisions and behaviors (Gómez-Mejía et al., 2007; Miller, Steier, \& Le Breton-Miller, 2003; Sharma \& Irving, 2005). Implicit in this line of reasoning is the observation - which is common in the family business literature - that family members view their businesses as something greater than a simple financial tool for profit maximization. An emotional logic drives their strategic decisions; they perceive the family business as part of their own identity and their most significant creation that needs to be preserved for future generations at all costs (Astrachan \& Jaskiewicz, 2008; Gómez-Mejía et al., 2007; Zellweger \& Astrachan, 2008). As such, the family business is an organization particularly vulnerable to the phenomenon of commitment escalation in the face of failing profitability (Gómez-Mejía et al., 2007; Salvato et al., 2010). Locked in a complex dichotomy between a powerful sense of commitment on the one hand, and the practicalities of fiscal reality on the other hand, members of a family business may find themselves trapped in a state of circularity if the family business begins to fail financially (Berrone, Cruz, \& Gómez-Mejía, 2012; Chirico \& Bau, 2014; Gómez-Mejía et al., 2010; 2011). In the sections that follow, we address the phenomenon of commitment escalation in family businesses and present its main critical antecedents: (a) differential degrees of emotional ownership, feeling of responsibility and investment of capital, (b) differential perspectives pertinent to the family generation in control, and (c) the extent to which the inculcated family value system is rooted in either an individualistic versus a collectivistic culture.

\section{PROPOSITIONS DEVELOPMENT}




\section{Emotional Ownership and Commitment Escalation}

Family members manifest a strong sense of attachment and identification to the business (Björnberg \& Nicholson, 2012). Founders and their heirs perceive the family business as their 'creature', and this bond often escalates their sense of commitment to an excessively high level (Miller et al., 2003; Salvato et al., 2010; Sharma \& Irving, 2005). In particular, we argue that, in the face of a failing situation (i.e., no longer a profitable entity), higher levels of emotional ownership can give rise to path dependency and thus ineffective strategies such as "hanging on" with the same product, strategy or business simply because it was adopted or created by ancestors during the past generations (Harris, Martinez, \& Ward, 1994; Miller et al., 2003). For example, Duhaime and Grant (1984, p. 303) explain that emotional attachments and identification with the firm often influence the process of decision-making in organizations, thereby “preventing earlier, more timely decisions”. Likewise, Burgelman (1994) and Keil (1995) found that when emotional logic prevails over business logic, members exert more energy defending their current course of action, ultimately inhibiting turnaround, regardless of an urgent need to do so.

Clearly, increased emotional ownership appears to play a critically influential role in decision-making processes, to the extent that it promotes family members' commitment escalation to their failing family business and works against change even in light of the justifiable need to do so (Olson et al., 2003; Sharma \& Manikutty, 2005; Sirmon \& Hitt, 2003). Higher levels of emotional ownership make family members able to tolerate negative results and continue the operation of the original founder's business formula for affective, rather than for profit reasons (De Tienne and Chirico, 2013; Kaye, 1996; Lansberg, 1988). 
Taken together, although we recognize that not all family members will have identical degrees of emotional ownership, we suggest that in general, increased emotional ownership on the part of family members renders the business a trap, thereby contributing to a state of commitment escalation with respect to their failing family business (Gómez-Mejía et al., 2011; Salvato et al., 2010). Stated more formally, we present this claim as:

Proposition 1: Increased emotional ownership is likely to lead to an increase in family members' commitment escalation to their failing family business.

Although existing studies have detailed how emotional considerations may affect family members’ strategic decisions in multiple contexts (e.g. Astrachan \& Jaskiewicz, 2008; GómezMejía et al., 2007, 2010; Zellweger \& Astrachan, 2008), it nonetheless remains unclear what intermediate variables facilitate and thus better explain the link between emotional considerations and family members’ strategic decisions. In the next sections we argue that feeling of responsibility and investment of capital mediate the emotional ownership / commitment escalation relationship described above.

\section{Feeling of Responsibility}

In line with self-justification theory, feeling of responsibility - the feeling of being personally responsible for a course of action (see Brockner, 1992; Staw, 1981), is an important psychological factor that can trigger the presence of commitment escalation regarding a failing business. In particular, it makes individuals feel compelled to justify their original decision, protect their initial idea, and their own reputation, both within and outside the firm (Staw \& Fox 1977; Whyte, 1986). Perceptions of responsibility go hand in hand with the extent to which one feels tied to a business enterprise, with high levels of these attributes serving to alter selfperceptions of efficacy and competence (Pierce et al., 2001; Van Dyne, \& Pierce, 2004). 
We argue that increased emotional ownership positively affects family members’ feeling of responsibility (Cater \& Schwab, 2008; Lumpkin, Martin, \& Vaughn, 2008; Salvato et al., 2010). As such, it stimulates the desire to take control of the business as part of their own identity and preserve it (Drozdow, \& Carroll, 1997; Kaye, 1996; Gómez-Mejía et al., 2007; Malone, 1989; Miller et al., 2003). Not surprisingly, when confronted with a deteriorating entrepreneurial scenario, family members tend to feel personally responsible for this event. Consequently, they tend to reject any notion of implausibility regarding its revitalization, and feel ashamed in entertaining any thoughts of change in the strategy, the product or the business as a whole (Jaffe \& Lane, 2004; Sirmon \& Hitt, 2003).

These reactions on the part of family members are clearly explained by higher levels of emotional ownership that serve to impact their justification motives, thereby precipitating an increased escalation of commitment to their failing business (Brockner, 1992; Sleesman et al., 2012; Staw, 1981). For example, Staw (1981), as well as Harrison and Harrell (1993) demonstrated that individuals are more committed to decisions for which they feel personally responsible. Furthermore, Walsh (1995) and Bazerman et al. (1998) have suggested that emotion is an important antecedent of an individual's feeling of responsibility towards any decision that may be undertaken. As such, increased emotional ownership makes family members feel a greater need to demonstrate and defend their own original decisions and initiatives, as well as those of others, e.g. previous generations, while, at the same time, protecting the family business’s reputation both within and outside the firm.

In general, family members tend to overestimate the likelihood of positive events and belief that previous negative outcomes can be reversed. For example, when attachment and identification with the business are high, some scholars (Gómez-Mejía et al., 2007; Kaye, 1996; 
Malone, 1989; Salvato et al., 2010) have argued that working from a strong feeling of responsibility and control tend to optimize family members' vision of the problem, regardless of how narrow it may be in perceiving a way to manage the fate of both the business and the family entity.

As a consequence of these aforementioned notions, family members who are highly attached, and manifest a strong sense of belonging to their business are likely to feel personal responsible for the decision taken and postpone the search for new and/or alternative opportunities of exploitation. As noted earlier, preserved responsibility leads them to view any potential losses as merely temporary circumstances, thus enhancing their commitment escalation to the failing family business. Stated more formally, we present our second claim as:

Proposition 2: Feeling of responsibility mediates the emotional ownership/commitment escalation relationship. That is, increased emotional ownership positively affects feeling of responsibility, thereby increasing the likelihood of family members' commitment escalation to their failing family business.

\section{Investment of Capital}

In line with self-justification theory, another important influencing psychological factor in the spawning of commitment escalation is that of investment of capital in the family business in terms of human resources (i.e., effort, energy, personal sacrifices, money, and time). Consistent with the impact of feeling of responsibility, discussed in the previous section, the greater the investment of capital resources in a family business, the more entrapped its family members become to their failing organization as justification for a prior behavior (Staw \& Fox 1977; Whyte, 1986). Again, we argue that increased emotional ownership makes family members increase the amount of value they place on the investment made by the family in the business, thus serving as a deterrent to changing a failing course of action. Paradoxically, it works in pressuring family members to invest more resources in efforts to save their failing 
business, thus leading to a state of entrapment (Kellermanns, Eddleston, Barnett, \& Pearson, 2008; Sharma, \& Manikutty, 2005; Sirmon \& Hitt, 2003; Zellweger, 2007).

As a result, in economic downturns, family members are induced by their emotional commitment and sense of trust and altruism, to supply extra-capital in the form of free labor, monetary loans, use of savings and the like (Chirico, Ireland \& Sirmon, 2011; Dreux, 1990; Olson et al., 2003). Indeed, Haynes et al. (1999, p.238) posit that "small businesses actively intermingle business and family resources” to preserve the business. Nonetheless, the same invested monetary and human capital may actually serve to dissuade family members from considering any degree of change such as, for example, releasing resources of their family business for reinvestment in a more profitable venture (Salvato et al., 2010; Sirmon \& Hitt, 2003). The latter factor is particularly true if those same resources contributed to any prior success of the failing business (see e.g., Jaffe, \& Lane, 2004; Keil, 1995; Sirmon \& Hitt, 2003). Investment of capital, driven by higher levels of emotional ownership, consequently serves as yet another psychological obstacle in the decision-making processes of the family business. In particular, it plays an important mediating role in dissuading family members from any consideration of change and instead, to continue investing more resources such that the original business formula and the business itself is maintained, albeit a failing one. For example, Gómez-Mejía et al. (2007) found that due to socioemotional wealth, family members tend to maintain family control and invest more resources despite the increased risk of poor performance. In order to justify the family's prior behavior and encumbered with the belief that an alternative course of action may lead to a loss of valued investments family members feel entrapped in the existing failing business and thus tend to invest additional resources to maintain 
the original founder's business formula despite the known problems it entails. Stated more formally, we present our third claim as:

Proposition 3: Investment of capital mediates the emotional ownership/commitment escalation relationship. That is, increased emotional ownership positively affects investment of capital, thereby increasing the likelihood of family members' commitment escalation to their failing family business.

Thus far, we have argued that family members typically focus on and become attached to their business, which they perceive as an extension of themselves. In failing situations, this perception can lead to inappropriate decisions that constrain change and favor entrapment to a failing organization. In particular, we have predicted that increased emotional ownership affects both family members' feeling of responsibility and investment of capital, thereby giving rise to a state of commitment escalation while masking the benefits of change initiatives.

Interestingly, the arguments theorized in our work thus far seem to find some practical evidence in the business world. For instance, Salvato et al. (2010) analyzed the strategic change that occurred in the Italian Falck Group - a successful family firm established in 1906 that became the largest privately held steel producer in Italy. Some years later, as a consequence of several environmental and industrial factors, the company experienced huge losses for a protracted period of time. However, only at a later point did these factors initiate the family's willingness to implement changes and look for alternative strategies. Alberto Falck, Chairman of the company in the 1980/90s mentions that it was the strong family’s attachment and identification to the business, coupled with a strong sense of family members' duty and highlevel investments that allowed the firm to continue bearing continued losses and still keep their commitment to the business without implementing changes.

A legitimate question that might be asked is - how some family organizations (e.g. the Falck Group), in order to ensure the survival and well-being of a failing family business, are able 
to ultimately adopt the changes needed to make this turnaround a reality? In other words, what circumstances are likely to trigger the turning point pertinent to the impact of emotional ownership on escalation of commitment to a failing family business, and at what point in time does this happen? In the sections that follow, we further distinguish family businesses based on the temporal distance from the founder business (e.g., Gómez-Mejía et al., 2007; Salvato et al., 2010) and the individualistic or collectivistic cultural context within which the family business operates (e.g., Sharma, \& Manikutty, 2005; Zellweger \& Astrachan, 2008). Both factors are considered to be critically important in differentiating sources of family-firm heterogeneity (Nordqvist, Sharma \& Chirico, 2014). We elaborate on the extent to which family members' considerations of entrapment and the potential inflection point mentioned above may vary across family businesses in accordance with their dependence on these two influential elements.

\section{Temporal Distance from the Founder's Business}

Some authors (Drozdow \& Carroll, 1997; Miller et al., 2003) have argued that even during subsequent generations, family members can remain locked in the past in the sense that the history of success of and strong ties to the family business shape and limit choices. In contrast, however, we claim this not to be the case. Rather, we contend that the more family members perceive themselves as being distanced from the founding roots of their firm (i.e., temporal distance from the founder’s business), the less likely they will feel attached to, and identify themselves with the business. Consequently, their feeling of responsibility and investment of capital towards their failing family business will tend to decrease, along with their escalation of commitment and tendency to delay or avoid change (see Gómez-Mejía et al., 2007; Salvato et al., 2010). It is worth nothing that given today's speed at which businesses either grow or fail, coupled with increasing age at marriage, the term "generations” may not be a useful 
operationalization of temporal distance. For this reason, our view of temporal distance reflects the actual years since the original business was formed, rather than the generation in control of the business.

The Falck case study presented earlier would appear to corroborate our argument here. Only after multiple decades from the founder's business, the Falck Group was able to implement a drastic and successful change. Accordingly, in 1996, it moved from the failing steel business to the successful renewable energy business. Federico Falck, Chairman of the Falck Group, explains that we were almost 100 years from foundation (and in the fifth generation) "when we discontinued the business, which means pretty far from the founders' motivations.” (Salvato et al., 2010, p. 340) Apparently, the passage of time reduced family members’ emotional ownership to the original founder's business (i.e. the steel industry) and the related family members' perception of responsibility and investments towards the failing activity. As a consequence, this enabled the transition to the new energy business.

Consistent with our claims related to temporal distance, Gómez-Mejía et al. (2007) reported findings that over time, family members’ personal attachment and identification with the firm, their familial cohesion, and their ability to exercise authority, tend to decrease thereby ultimately facilitating change (e.g., joining a cooperative for which decision-making is associated with a loss of family control but, more importantly, with lower business risks and increased chances of long-term survival). Likewise, Kellermanns and Eddleston (2006) state that as time passes, family members often push for new ways of doing things in an effort to adapt the organization to the shifting environment. Thus, there are likely to be important differences in the extent to which members of family businesses at different ages feel entrapped in the organization and are willing to make important changes (Sciascia, Mazzola \& Chirico, 2013). 
In summary, initially family members controlling the family business are likely to exhibit the least amount of willingness to change, thereby inadvertently increasing the presence of commitment escalation to their failing business. In contrast, the more distant the memories of the firm’s historical development, the more likely family members will be to make decisions leading to change. That is, lower emotional ownership leads to a lower feeling of responsibility for, and investment of capital in the family business which, in turn, inhibits commitment escalation and works in favor of change that enables family owners and managers to sustain the same level of growth of the past (Jaffe \& Lane, 2004; Salvato et al., 2010). Stated more formally, we present our fourth claim as:

Proposition 4: Temporal distance from the founder's business negatively affects emotional ownership and thus feeling of responsibility and investment of capital, thereby decreasing the likelihood of family members' commitment escalation to their failing family business.

\section{Individualistic versus Collectivistic Family Business Milieux}

Individualism and collectivism, as defined by VandenBos (2007, p.195), represent the tendency to view oneself as an isolated independent being or a member of a larger (family or social) group, respectively (Hofstede, 2001). Historically, this ideological perspective pervades the cross-cultural psychological literature wherein research has generally categorized groups, cultures or societies as being either individualistic or collectivistic based on the value placed on one's sense of individuality or sense of community. There is some suggestion in the organizational literature that individualism/collectivisim may impart a strong influence on an individual's sense of commitment and persistance in pursuing particular courses of action. For example, Felfe, Yan, and Six (2008) reported individualism and collectivism to exert a strong influence on commitment. As expected, however, they found that commitment is most intense in cultures generally classified as being collectivistic in nature. 
Within this collectivistic framework, family members are part of a close-knit group in which each individual identifies with the larger family collective (Sharma \& Manikutty, 2005). Such identity facilitates the emergence of norms and maintains trustworthiness among family members (Miller \& Le Breton-Miller, 2005). Altough this notion of collectivism may be the glue that binds members of the family business together, it may not always be the case (Sharma \& Manikutty, 2005; Zellweger \& Astrachan, 2008). Based on individualism-collectivism dimensions proposed by Hofstede (2001), Sharma and Manikutty (2005) postulated that strategic change and inertia might differ depending on the extent to which an organization is embedded in a collectivistic or an individualistic culture. Indeed, Zellweger and Astrachan (2008) theorize that in collectivistic cultures, family business units are created and operated to meet the noneconomic motives of the family collective, which can hamper the implementation of radical changes (see also Zahra, Hayton \& Salvato, 2004).

Conversely, in individualistic community cultures, family members' focus is more on the financial rather than on the emotional value of the family business. Thus, family businesses in individualistic cultures may be merely economic units that are guided by economic principles, such as maximization of returns. Zellweger and Astrachan (2008, p. 356) posit that family businesses "in individualistic societies are therefore less driven by social constraints and nonfinancial aspects of the ownership stake that would build attachment...In comparison with owners whose firms are embedded in collectivistic cultures, [family] owners operating in individualistic ones are less likely to feel emotional attachment to their ownership stake.” Consistent with the arguments of Zellweger and Astrachan (2008), Björnberg and Nicholson (2012) also view family climate in terms of family dynamics and relationships as an important antecedent to emotional ownership in family business. 
Following this line of thought, it seems reasonable to expect that in a failing situation when the extended family is held in high regard, thereby exemplifying a primary characteristic of collectivistic cultures, emotional ownership will further increase, thus favoring family members' commitment escalation to their failing business. Alternatively, a family business for which its value system is characterized by an emphasis on the importance of independence and individuality, will negatively affect family members’ emotional ownership, as well as their feeling of responsibility and investment of capital, thereby reducing their sense of entrapment in the business while concomitantly facilitating the implementation of change initiatives. Stated more formally, we present our fifth claim as:

Proposition 5: Individualism negatively affects emotional ownership and thus feeling of responsibility and investment of capital, thereby decreasing the likelihood of family members' commitment escalation to their failing family business.

\section{DISCUSSION}

In writing this article, we hope that we have heightened awareness to: (a) the construct of commitment escalation as it relates to a failing family business in need of change, and (b) the need for critically important construct validity research in order to establish a strong theoretical base to which it can be grounded. Drawing on the concept of emotional ownership combined with self-justification, we have identified those factors (i.e. emotional ownership, feeling of responsibility, investment of capital, temporal distance from the founder's business, individualism/collectivism) that we consider to be primary determinants of commitment escalation.

Our theoretical work offers several important contributions to the family business literature. First, to the best of our knowledge, this work is ground-breaking in its focus on the concept of commitment escalation within the framework of the family business, which is 
typically characterized by heightened emotional and social attachments. Focusing on the antecedents of commitment escalation in a family firm context allowed us to expand existing family-business research into a relatively new research field that, with few exceptions (e.g. De Tienne \& Chirico, 2013; Salvato et al., 2010; Sharma \& Manikutty, 2005; Woods et al., 2012), has remained understudied. Specifically, it answers a recent call for research to examine in a family firm context "escalation of commitment leading individuals [family members] to become locked into costly courses of action after encountering increased problems or losses” (Dawson et al., 2015: 562). In particular, our commitment escalation research work has shown that a family business that continues to 'throw good money after bad' is highly disadvantageous in at least three important ways: (a) through the infusion of additional money, the business totally fails in resolving any major financial problem, (b) through the escalation of resource use, the firm only continues to waste valuable resources, and (c) through the loss of opportunity to benefit from alternative use of resources.

Second, our work extends the efforts of several previous family-business studies (e.g. Astrachan \& Jaskiewicz, 2008; Gómez-Mejía et al., 2007; Sirmon \& Hitt, 2003; Zellweger \& Astrachan, 2008) to explain family business strategic decisions and behaviors as being consequential to the direct effect of family members' emotional states and/or non-financial issues, albeit with total reliance on terminologies having similar meanings (e.g. emotional ties, psychological ownership, socio-emotional wealth, emotional value, emotional returns etc.). In contrast, we detail potential antecedents of family members' emotional ownership, together with intermediate mediating factors that affect family members' escalation of commitment to a failing business (see Figure 1). In so doing, we better explain the mechanisms underlying the emotions/strategic decision relationship in family firms. In addition, our work extends the work 
of Björnberg and Nicholson (2012, p. 381) in that it considers emotional ownership, not only as “the relationship between the NxG [next generation] family member and the business”, but also, as the emotional bond between family members in general and the business.

Third, many scholars (Bazerman et al., 1998; Sleesman et al., 2012; Walsh, 1995) portray previous literature on organizational decision-making as inadequate and incomplete. For example, Sleesman et al. (2012, p. 557) recently suggested that the literature on commitment escalation "has been insightful and interesting over the years", but has not paid enough attention to “social or structural factors [e.g. group identity, attachment, cohesiveness strength].” In fact, extant research has focused mainly on the cognitive aspects of decision- making at the expense of an adequate investigation of the role played by emotions (Bazerman et al., 1998; Walsh, 1995); a view that is supported by multiple empirical works (e.g., Wong \& Kwong, 2007; Wong, Yik \& Kwong, 2006). These efforts underscore the need to understand the role of emotions in decision making as crucial to advancing our understanding of commitment escalation. In contrast to these earlier works, we address these limitations by combining the commitment escalation literature with the concept of emotional ownership, thereby making an important contribution to both the existing family business (e.g. Salvato et al., 2010; Sharma \& Manikutty, 2005; Woods et al., 2012) and the industrial/organizational psychological literatures (e.g., Schultze, Pfeiffer, \& Schulz-Hardt, 2012; Sleesman et al., 2012).

Our theory suggests that increased emotional ownership can cause family owners to feel locked into a business and thus harms the potential gains of change initiatives. In this regard, De Tienne and Chirico (2013) and Berrone et al. (2012) invite scholars to direct more research attention toward the negative side of family members' non-financial and specifically affective goals. Family members' emotional ownership is often viewed as an affective asset; yet, our work 
suggests that in some situations (e.g. when the business is in a failing situation) it may also be an affective liability that favors entrapment and constrains change initiatives. We believe that our work offers a deeper understanding of the commitment escalation phenomenon within a context in which emotions bear importantly on the decision-making processes. Nonetheless, additional work may focus on other specific theoretical concepts such as group identity and cohesiveness strength (Sleesman et al., 2012) or on the different dimensions of socioemotional wealth identified by Berrone et al. (2012) - family control and influence, family member identification with the firm, binding social ties, emotional bonds, and the intention to hand the business down to future generations.

Fourth, we theorize that family firms are heterogeneous and thus behave differently ((Nordqvist et al., 2014; Sharma, 2004). We contend that emotional ownership and temporal distance from the founder's business, in addition to an individualistic or collectivistic cultural milieu, are important differentiators that explain why family members support or inhibit change in family businesses. In particular, our focus on temporal distance from the founder's business in terms of firm age rather than of generation in control makes our work unique and different from most previous research focused on the effect of family generation in control on multiple family business outcomes.

A final contribution of the present study is the possibility that our work may help researchers to better understand commitment escalation as it relates to other business enterprises. For example in this article, we have focused on the uniqueness of the family business as a consequence of its historical roots, as well as its need to deal with the presence of commitment escalation when faced with a failing situation. However, it may well be that this same 
emotionally based conundrum occurs in other organizational entities in which social relationships and/or emotions play important roles (e.g. founder firms, non-profit organizations).

\section{Future Research}

The material presented in this article is intended to serve as a point of departure for guiding and pushing forward with related theoretical and empirical research. It seems evident that, at this point in time, the construct of commitment escalation is clearly in an embryonic state in family business research and therefore in need of substantial validation work capable of anchoring it to a solid theoretical base. Indeed, this critically important requirement opens the window to a world of opportunities for future research. We have verbally explored the importance of emotional ownership, feeling of responsibility, and investment of capital, as they relate to the family business. Likewise, we have rationalized that temporal distance from the founder's business, as well as the impact of an individualistic and collectivistic milieu, can also serve as determinants of commitment escalation, which has been claimed to occur in the face of failing courses of action that require change initiatives. Importantly, however, these postulated causal links need to be empirically tested in order to: (a) establish their viability, and (b) provide a springboard for all subsequent research. This research necessarily involves both methodological and substantive research, the former being a prerequisite for the latter. We now suggest a program of research that we believe would advance and make important contributions to the field.

\section{Future Methodological Research}

Confirmation of the impact of emotional ownership, feeling of responsibility, investment of capital, temporal distance and individualism on commitment escalation can serve as a first step in the process of validating the construct itself with a view to rooting it in a solid theoretical 
base. In other words, before commitment escalation can be fully understood, the theoretical structure of the construct must be determined. In particular, it is necessary to first identify and test for the validity of its nomological network (Cronbach \& Meehl, 1955), which initiates the process of testing for its construct validity (for a practical application of nomological network validation, readers are referred to Byrne, 1999, 2006, 2009, 2011). From such research, we can assess (a) relations between commitment escalation and other constructs with which it is empirically related (i.e., between-network relations), and (b) relations among the dimensions of commitment escalation itself (within-network relations). Determination of a viable nomological network represents the first step in building a theory of commitment escalation in family business.

One methodological approach that lends itself extremely well to testing for construct validity, and particularly as it bears on the construct's nomological network, is structural equation modeling as it enables the researcher both to model relations among associated constructs and to test for the validity of these hypothesized relations (see Byrne, 2006, 2009, 2011). A logical follow-up to this theoretical validation research is the development of a psychometrically sound measuring instrument capable of tapping all dimensions of the commitment escalation construct, as determined in the initial construct validation process. Subsequently, scores derived from the application of this instrument will need also to be validated. Tests based on the application of confirmatory factor analytic models are the modus operandi in this case. Empirical research can then move forward in the investigation of related substantive issues focused on commitment escalation. As mentioned earlier, in Table 1 we suggest potential items that may be useful in measuring our constructs of interest in a sample of family businesses being no longer profitable. As such, scholars may focus on companies 
experiencing financial losses for multiple years (see Salvato et al., 2010), and/or in financial distress — predicting the probability that a firm will enter bankruptcy within two years; see Altman, 1968; 1983). In particular, to test our theoretical model, among others, a test to control for endogeneity will be required. For instance, the relationships we theorized may be subject to a reverse causality interpretation; feeling of responsibility, investment of capital and commitment escalation might lead to increased emotional ownership.

- Insert Table 1 about here -

\section{Future Substantive Research}

First, our theoretical framework could be advanced by considering other relevant constructs such as social capital in terms of family and non-family relations within and outside the firm (Arregle et al., 2007). Also, one may explore how commitment escalation may vary among family members within the same generation. Second, future studies may wish to explore whether moderate levels of emotional ownership may have positive effects on family firm change-initiatives, especially in a failing circumstance. For instance, in line with Propositions 4 and 5, moderate levels of emotional ownership that positively affect family firm outcomes in failing situations may be reached when the family firm is temporally far away from the original founding business and an individualistic culture predominates. Third, we urge future studies that empirically test the extent to which the emotional ownership/change initiatives relationship may be curvilinear (inverted U-shaped) such that lower levels of emotional ownership positively affects family firms' strategic changes whereby increased (e.g., "too much”) emotional ownership generates rigidities which have negative effects on family members' strategic decisions in times of negative performance.

Another avenue of substantive research lies with the need to investigate relevant de- 
commitment strategies that can reduce individuals’ entrapment to failing courses of action. Such research may help promoting a better understanding of how to overcome resistance to change in family businesses. For example, Duhaime and Schwenk (1985), as well as Deily (1991) have suggested the hiring of external consultants, while Keil and Robey (1999) have proposed the need for the regular evaluation of individual projects as well as of the business itself. Likewise, de-commitment strategies that enable the overcoming of psychological barriers may be initiated through retrenchment, top-management changes (e.g. the presence of a non-family CEO) and infusion of external management expertise (Cater \& Schwab, 2008), as well as the incisive action of family champions of change (Salvato et al., 2010).

Additionally, future studies may shed some light on recent findings that "during good economic times, family-run companies don’t earn as much money as companies with a more dispersed ownership structure. But when the economy slumps [in times of crisis], family firms far outshine their peers” given their focus on resilience rather than short-term performance (Kachaner, Stalk \& Bloch, 2012, p. 104). Finally, it would be of interest to explore the extent to which the determinants of commitment escalation, as proposed in this article and/or as revealed in future research, hold across other forms of organizations, such as founder and non-profit organizations, and what are the resulting family and business consequences.

\section{Implications for Practice}

Our work has also practical implications for family business management. Family members must be acutely cognizant of the need to respond quickly to negative outcomes. The first step is for family members to recognize that humans have a natural tendency to escalate their efforts when they become too committed to a course of action, and that this effect can be 
amplified and turned into entrapment within a family business context. Accordingly, efforts must be made to distinguish between financial and non-financial considerations.

Individuals become entrapped into a course of action partially because they are not aware of the costs associated with remaining in a specific situation. Thus, to avoid entrapment, it is crucial to implement early warning systems that help family members to detect entrapment to their failing family business as early as possible. One approach is to set specific minimum target levels below which failure would be recognized and lead to a change in action (Brockner \& Rubin, 1985). Other approaches are to evaluate the business both internally and externally periodically, to make visible and transparent the costs related to a failing business, and/or to hire outsiders such as consultants or a new CEO. Family members need to develop the habit of seeing time as a stream such that issues are viewed in the present with a sense of historical currents, as well as with an eye to the future. It is thus important to question old patterns of strategic action and explore new ones continuously.

We trust that our work will kindle and escalate research important in furthering our understanding of commitment entrapment in failing family business enterprises in need of change. 


\section{References}

Altman EI. (1968) Financial ratios, discriminant analysis and the prediction of corporate bankruptcy. Journal of Finance, 23, 189-209.

Altman EI. 1983. Corporate Distress: A Complete Guide to Predicting, Avoiding, and Dealing with Bankruptcy. New York: Wiley.

Altman EI. (2000). Predicting Financial Distress of Companies. Retrieved on September 4th, 2009 from http://pages.stern.nyu.edu/ ealtman/Zscores.pdf: 15-22.

Arregle, L., Hitt, M., Sirmon, D., \& Very, P. (2007). The development of organizational social capital: Attributes of family firms. Journal of Management Studies, 44, 73-95.

Ashforth, B. E., \& Mael, F. (1989). Social identity theory and the organization. Academy of Management Review, 14, 20-39.

Astrachan, J. H., \& Jaskiewicz, P. (2008). Emotional returns and emotional costs in privately held family businesses: Advancing traditional business valuation. Family Business Review, 21, 139-149.

Bazerman, M., Tenbrunsel, A. E., \& Wade-Benzoni, K. (1998). Negotiating with yourself and losing: Making decisions with competing internal preferences. Academy of Management Review, 23, 225-241.

Berrone, P., Cruz, C. C., \& Gómez-Mejía, L. R. (2012). Socioemotional wealth in family firms: A review and agenda for future research. Family Business Review, 25(3): 258-279.

Björnberg A. \& Nicholson N. (2012). Emotional ownership: The next generation's relationship with the family firm. Family Business Review, 5(4) 374-390

Brockner, J. (1992). The escalation of commitment to a failing course of action: Toward theoretical progress. Academy of Management Review, 17, 39-61.

Brockner, J., Houser, R., Birnbaum, G., Lloyd, K., Deitcher, J., Nathanson, S., \& Rubin, J. Z. (1986). Escalation of commitment to an ineffective course of action: the effect of feedback having negative implications for self-identity, Administrative Science Quarterly, 31, 109_ 126.

Brockner, J., \& Rubin, J. Z. (1985). Entrapment in escalating conflicts. New York: SpringerVerlag.

Brockner, J., Rubin, J. E., \& Lang, B. (1981). Face-saving and entrapment. Journal of Experimental Social Psychology, 17, 68-79.

Brockner, J., Shaw, M.C., \& Rubin, J. Z. (1979). Factors affecting withdrawal from an escalating conflict: Quitting before it's too late. Journal of Experimental Social Psychology, 15, 492503.

Burgelman, R. A. (1994). Fading memories: A process study of strategic business exit in dynamic environments. Administrative Science Quarterly, 39, 24-56.

Byrne, B. M. (1999). The nomological network of teacher burnout: A literature review and empirically validated model. In R.Vandenberghe, \& A.H. Huberman (Eds.), Understanding and preventing teacher burnout: A sourcebook of international research and practice (pp. 15-37). Cambridge, UK: Cambridge University Press.

Byrne, B. M. (2006). Structural equation modeling with EQS: Basic concepts, applications, and programming (2nd ed.). Mahwah, NJ: Erlbaum.

Byrne, B. M. (2009). Structural equation modeling with AMOS: Basic concepts, applications, and programming (2nd ed.). New York: Taylor \& Francis/Routledge.

Byrne, B. M. (2011). Structural equation modeling with Mplus: Basic concepts, applications, and programming. New York: Taylor \& Francis/Routledge. 
Cater, J., \& Schwab, A. (2008), Turnaround strategies in established small family firms. Family Business Review, 21, 31-50.

Chirico F. and Bau M. (2014) Is the Family an 'Asset' or 'Liability' for Firm Performance? The Moderating Role of Environmental Dynamism. Journal of Small Business Management, 52, 210-225

Chirico, F., Ireland R. D., \& Sirmon D. G. (2011). Franchising and the family firm: Creating unique sources of advantage through 'familiness.' Entrepreneurship Theory \& Practice 35(3), 483-501.

Cronbach, L. J., \& Meehl, P. E. (1955). Construct validity in psychological tests. Psychological Bulletin, 52, 281-302.

Davis, P., \& Harveston, P. (1999). In the founder's shadow: Conflict in the family firm. Family Business Review, 7, 311-323.

Dawson A., Sharma P., Irving PG., Marcus J., \& Chirico F. (2015). Predictors of Later Generation Family Members’ Commitment to Family Enterprises. Entrepreneurship Theory and Practice, 39, 545-569.

Deily, M. E. (1991). Exit strategies and plant-closing decisions: The case of steel. Rand Journal of Economics, 22, 250-263.

De Tienne D. and Chirico F. (2013). Exit Strategies in Family Firms: How Socioemotional Wealth drives the Threshold of Performance. Entrepreneurship Theory and Practice, 37, 1297-1318.

Dreux, D. R. (1990). Financing family business: Alternatives to selling out or going public. Family Business Review, 3, 225-243

Drozdow, N., \& Carroll, V. (1997). Tools for strategy development in the family firm. Sloan Management Review, 39, 75-88.

Drummond, H. (2001) The Art of Decision Making, Mirrors of Imagination, Masks of Fate. John Wiley \& Sons Ltd, West Sussex.

Duhaime, I. M., \& Grant, J. H. (1984). Factors influencing divestment decision-making: Evidence from a field study. Strategic Management Journal, 5, 301-318.

Duhaime, I. M., \& Schwenk, C. R. (1985). Conjectures on cognitive simplification in acquisition and divestment decision making. Academy of Management Review, 10, 287-295.

Eisenhardt, K. M., \& Martin, J. A. (2000). Dynamic capabilities: What are they? Strategic Management Journal, 21, 1105-1121.

Felfe, J., Yan, W., \& Six, B. (2008). The impact of individual collectivism on commitment and its influence on organizational citizenship behaviour and turnover in three countries. International Journal of Cross Cultural Management, 8, 211-237.

Gómez-Mejía, L. R., Cruz, C., Berrone, P., \& De Castro, J. (2011). The Bind that Ties: Socioemotional Wealth Preservation in Family Firms. The Academy of Management Annals, 5, 653-707.

Gómez-Mejía, L. R., Haynes, K. T., Núñez-Nickel, M., Jacobson, K. J. L., \& Moyano-Fuentes, J. (2007). Socioemotional wealth and business risks in family-controlled firms: Evidence from Spanish olive oil mills. Administrative Science Quarterly, 52, 106-137.

Gómez-Mejía, L. R., Makri, M., \& Larraza-Kintana, M. (2010). Diversification decisions in family-controlled firms. Journal of Management Studies, 47, 223-252.

Harris, D., Martinez, J. I., \& Ward, J. L. (1994). Is strategy different for the family-owned business? Family Business Review, 7, 159-174. 
Harrison, P., \& Harrell, A. (1993). Impact of “adverse selection” on managers’ project evaluation decisions. Academy of Management Journal, 36, 635-643.

Haynes, G.W., Walker, R., Rowe, B. R., \& Hong, G. S. (1999). The intermingling of business and family finances in family-owned businesses. Family Business Review, 7, 225-239.

Hofstede, G. (2001). Culture's consequences (2nd ed.). Thousand Oaks, CA: Sage.

Jaffe, D., \& Lane, S. (2004). Sustaining a family dynasty: Key issues facing complex multigenerational business- and investment-owning families. Family Business Review, 17, 7-28.

James, H. (1999). Owner as manager, extended horizons and the family firm. International Journal of Economics of Business, 6, 41-56.

Kachaner, N., Stalk, G., \& Bloch, A. (2012). What you can learn from family business. Harvard Business Review, 90(11), 102-106.

Kaye, K. (1996). When the family business is a sickness. Family Business Review, 9, 347-368.

Kaye, K. (1998). Happy landings: The opportunity to fly again. Family Business Review, 11, 275-280.

Keil, M. (1995). Pulling the plug: Software project management and the problem of project escalation. MIS Quarterly, 19, 421-447.

Keil, M., Mann, J., \& Rai, A. (2000). Why software projects escalate: An empirical analysis and test of four theoretical models. MIS Quarterly, 24, 631-664.

Keil, M., \& Robey, D. (1999). Turning around troubled software projects: An exploratory study of the de-escalation of commitment to failing courses of action. Journal of Management Information Systems, 15, 63-87.

Kellermanns, F. W., \& Eddleston, K. (2006). Corporate entrepreneurship in family firms: A family perspective. Entrepreneurship Theory and Practice, 30, 809-830.

Kellermanns, F. W., Eddleston, K. A., Barnett, T., \& Pearson, A. (2008), An exploratory study of family member characteristics and involvement: Effects on entrepreneurial behavior in the family firm. Family Business Review, 21, 1-14.

Lansberg, I. (1988). The succession conspiracy. Family Business Review, 1, 119-143.

Li, F., \& Aksoy, L. (2007). Dimensionality of individualism-collectivism and measurement equivalence of Triandis and Gelfand's scale. Journal of Business and Psychology, 21, 313329.

Ling, Y. \& Kellermanns, F. W. (2010). The effects of family firm specific diversity: The moderating role of information exchange frequency. Journal of Management Studies 47, 332-344.

Lopes, L. L. (1987). Between hope and fear: The psychology of risk. Advances in Experimental Social Psychology, 20, 255-295.

Lumpkin, G. T., Martin, W., \& Vaughn, M. (2008). Family orientation: Individual-level influences on family firm outcomes. Family Business Review, 21, 127-138.

Malone, S. C. (1989). Selected correlates of business continuity planning in the family business. Family Business Review, 2, 341-353.

Meyer, J.P. \& Allen, N.J. (1991). A three-component conceptualization of organizational commitment. Human Resource Management Review, 1, 61-89.

Meyer, J.P. \& Herscovitch, L. (2001). Toward a general model of commitment. Human Resource Management Review, 11, 299-326.

Miller, D. (1990). The Icarus paradox. New York: HarperBusiness. 
Miller, D., \& Le Breton-Miller, I. (2005). Managing for the long run: Lessons in competitive advantage from great family businesses. Boston, MA: Harvard Business School Press.

Miller D., Steier L., \& Le Breton-Miller, I. (2003). Lost in time: Intergenerational succession, change, and failure in family business. Journal of Business Venturing, 18, 513-531.

Nicholson, N. (2008). Evolutionary psychology and family business: A new synthesis for theory, research, and practice. Family Business Review, 21, 103-118.

Nordqvist M., Sharma P. \& Chirico F. (2014). Family Firm Heterogeneity and Governance: A Configuration Approach. Journal of Small Business Management, 52, 192-209

Olson, P. D., Zuiker, V. S., Danes, S. M., Stafford, K., Heck, R. K. Z., \& Duncan, K. A. (2003). The impact of family and business on family business sustainability. Journal of Business Venturing, 18, 639-666.

Pierce, J., Kostova, T., \& Dirks, K. (2001). Toward a theory of psychological ownership in organisations. Academy of Management Review, 26, 298-310.

Randall, D. (1987). Commitment and the organization: the organization man revisited, Academy of Management Review, 12(3), 460-471.

Rosenblatt, P. (1991). The interplay of family system and business system in family farms during economic recession. Family Business Review, 4, 45-57.

Salvato, C., Chirico, F., \& Sharma, P. (2010). A farewell to the business: Championing exit and continuity in entrepreneurial family firms. Entrepreneurship \& Regional Development, 22, 321-348.

Schulz-Hardt, S., Thurow-Kröning, B., \& Frey, D. (2009). Preference-based escalation: A new interpretation for the responsibility effect in escalating commitment and entrapment. Organizational Behavior and Human Decision Processes, 108, 175-186.

Schultze, T., Pfeiffer, F., \& Schulz-Hardt, S. (2012). Biased information processing in the escalation paradigm: Information search and information evaluation as potential mediators of escalating commitment. Journal of Applied Psychology, 97, 16-32.

Sciascia S., Mazzola P. \& Chirico F. (2013). Generational involvement in the top management team of family firms: Exploring non-linear effects on entrepreneurial orientation. Entrepreneurship Theory and Practice, 37(1), 69-85

Sharma, P. (2004). An overview of the field of family business studies: Current status and directions for the future. Family Business Review, 17(1), 1-36.

Sharma P., \& Irving P. G. (2005). Four bases of family business successor commitment: Antecedents and consequences. Entrepreneurship Theory and Practice 29, 13-33.

Sharma, P., \& Manikutty, S. (2005). Strategic divestments in family firms: Role of family structure and community culture. Entrepreneurship Theory and Practice, 29, 293-312.

Sirmon, D. G., \& Hitt, M. A. (2003). Managing resources: Linking unique resources, management and wealth creation in family firms. Entrepreneurship Theory and Practice, 27, 339-358.

Sleesman, D. J., Conlon, D. E., McNamara, G., \& Miles, J. E. (2012). Cleaning up the big muddy: A meta-analytic review of the determinants of escalation of commitment. Academy of Management Journal, 55, 541-562.

Staw, B. M. (1976). Knee deep in the big muddy: A study of escalating commitment to a chosen course of action. Organizational Behavior and Human Performance, 16, 27-44.

Staw, B. M. (1981). The escalation of commitment to a course of action. Academy of Management Review, 6, 577-587. 
Staw, B. M. (1997). The escalation of commitment. In Z. Shapira (Ed.), Organizational decision making (pp. 191-215). New York: Cambridge University Press.

Staw, B.M. \& Fox, F. (1977). Escalation: Some determinants of commitment to a previously chosen course of action, Human Relations, 30, 4431-4450.

Triandis, H. C. \& Gelfand, M. J. (1998). Converging measurement of horizontal and vertical individualism and collectivism. Journal of Personality and Social Psychology, 74, 118-128.

Van de Ven, A. H., \& Poole, M. S. (1995). Explaining development and change in organizations. Academy of Management Review, 20, 510-40.

Van Dyne, L., \& Pierce, J. (2004). Psychological ownership and feelings of possession: Three field studies predicting employee attitudes and organizational citizenship behaviour. Journal of Organizational Behavior, 25, 439-459.

VandenBos, G. R. (2007). APA dictionary of psychology. Washington, DC: American Psychological Association.

Walsh, J. P. (1995). Managerial and organizational cognition: Notes from a trip down memory lane. Organization Science, 6, 280-321.

Whyte, G. (1986). Escalating commitment to a course of action: A reinterpretation. Academy of Management Review, 11(2), 311-321.

Whyte, G. (1993). Escalating commitment in individual and group decision making: A prospect theory approach. Organizational Behavior and Human Decision Processes, 54, 430-445

Wilson, R. M. S., \& Zhang, Q. (1997). Entrapment and escalating commitment in investment decision making: A review, British Accounting Review, 29, 277-305.

Wong, K. F. E., \& Kwong, J. Y. Y. (2007). The role of anticipated regret in escalation of commitment. Journal of Applied Psychology, 92, 545-554.

Wong, K. F. E., Yik, M., \& Kwong, J. Y. Y. (2006). Understanding the emotional aspects of escalation of commitment: The role of negative affect. Journal of Applied Psychology, 91, 282-297.

Woods, J. A., Dalziel, T., \& Barton, S. L. (2012). Escalation of commitment in private family businesses: The influence of outside board members. Journal of Family Business Strategy, 3(1), 18-27.

Yuen, K. C., \& Hamilton, R. T. (1993). Corporate divestment: An overview. Journal of Managerial Psychology, 8, 9-13.

Zahra, S. A. (2005). Entrepreneurial risk taking in family firms. Family Business Review, 18, 2340.

Zahra S. A., Hayton J., \& Salvato C., (2004). Entrepreneurship in family vs. non-family firms: A resource-based analysis of the effect of organizational culture. Entrepreneurship Theory and Practice, 29, 363-382.

Zellweger, T. (2007). Time horizon, costs of equity capital, and generic investment strategies of family firms. Family Business Review, 20, 1-15.

Zellweger, T. M., \& Astrachan, J. H. (2008). On the emotional value of owning a firm. Family Business Review, 21, 347-363. 


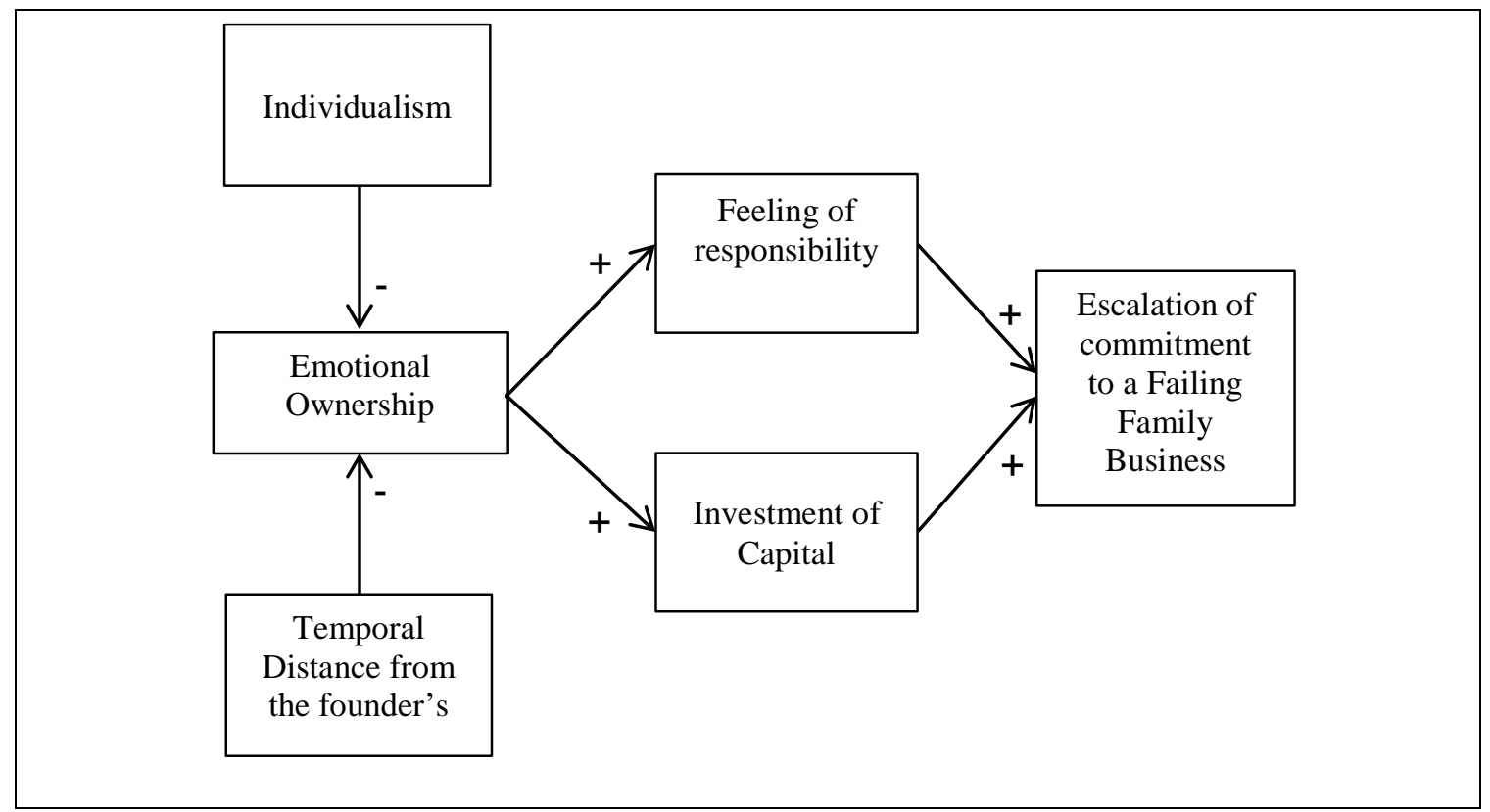

Figure 1. Conceptual Model of Commitment Escalation pertinent to a Failing Family Business 


\section{Table 1}

\section{Potential Measurement Items}

Please, rate your degree of agreement with the following statements ( $1=$ strongly disagree; $5=$ strongly agree)

\begin{tabular}{|c|c|c|}
\hline Constructs & Items & References \\
\hline Emotional Ownership & $\begin{array}{l}\text { 1) We feel as if we belong to the family business } \\
\text { 2) We care about the family business } \\
\text { 3) We feel detached from the family business (R) } \\
\text { 4) We feel close to the family business } \\
\text { 5) The family business is an important part of who we } \\
\text { are } \\
\text { 6) The fate of the family business is not relevant to us } \\
\text { (R) } \\
\text { 7) We identify with the family business } \\
\text { 8) What happens to the family business matters to us }\end{array}$ & $\begin{array}{l}\text { (Björnberg \& } \\
\text { Nicholson, } \\
\text { 2012) }\end{array}$ \\
\hline $\begin{array}{l}\text { Feeling of } \\
\text { responsibility }\end{array}$ & $\begin{array}{l}\text { 1) Family members repeatedly express support and feel } \\
\text { responsible for the family business } \\
\text { 2) Family members often feel the need to justify their } \\
\text { original decision } \\
\text { 3) Family members often feel the need to protect their } \\
\text { reputation within the firm } \\
\text { 4) Family members often feel the need to protect their } \\
\text { reputation outside the firm }\end{array}$ & $\begin{array}{l}\text { (Keil, Mann \& } \\
\text { Rai, 2000; } \\
\text { Salvato et al., } \\
\text { 2010; Sirmon } \\
\text { and Hitt, 2003) }\end{array}$ \\
\hline Investment of Capital & $\begin{array}{l}\text { 1) Family members devote a large amount of energy, } \\
\text { efforts, personal sacrifices, money and time for the } \\
\text { family business } \\
\text { 2) Family members often refer to past investments in } \\
\text { the business } \\
\text { 3) Family members highly value the resources put in } \\
\text { the family business by the family } \\
\text { 4) Investments of resources are high in the family } \\
\text { business }\end{array}$ & $\begin{array}{l}\text { (Keil, Mann \& } \\
\text { Rai, 2000; } \\
\text { Salvato et al., } \\
\text { 2010; Sirmon } \\
\text { and Hitt, 2003) }\end{array}$ \\
\hline Temporal Distance & $\begin{array}{l}\text { 1) Please, indicate how many years passed by from the } \\
\text { foundation of the business }\end{array}$ & $\begin{array}{l}\text { (Ling \& } \\
\text { Kellermanns, } \\
\text { 2010) }\end{array}$ \\
\hline Individualism & $\begin{array}{l}\text { 1) Parents and children must stay together as much as } \\
\text { possible (R) } \\
\text { 2) It is our duty to take care of our family, even when } \\
\text { we have to sacrifice what we want (R) } \\
\text { 3) Family members should stick together, no matter } \\
\text { what sacrifices are required (R) } \\
\text { 4) It is important to us that we respect the decisions } \\
\text { made by the family (R) } \\
\text { 5) If a family member gets a prize, we would feel } \\
\text { proud (R) } \\
\text { 6) The well-being of family members is important to us } \\
\text { (R) } \\
\text { 7) For us, pleasure is spending time with others (R) } \\
\text { 8) We feel good when we cooperate with each other } \\
\text { (R) } \\
\text { 9) Our actions are driven by individualistic } \\
\text { considerations }\end{array}$ & $\begin{array}{l}\text { (Triandis \& } \\
\text { Gelfand, 1998; } \\
\text { Li \& Aksoy, } \\
\text { 2007) }\end{array}$ \\
\hline
\end{tabular}




\begin{tabular}{|c|c|c|}
\hline & 10) Generally, we have an individualistic culture & \\
\hline Commitment Escalation & $\begin{array}{l}\text { Subjective measure: } \\
\text { 1) It seems foolish not to continue the family business } \\
\text { in the same fashion } \\
\text { 2) We want to keep running the family business } \\
\text { following the same logic of our predecessors } \\
\text { 3) Changes in our strategy, program, products or the } \\
\text { overall organizations are important and necessary in } \\
\text { our business (R) } \\
\text { 4) We can easily control the fate of our family business } \\
\text { in the present and future }\end{array}$ & $\begin{array}{l}\text { (Brockner et } \\
\text { al., 1986; } \\
\text { Schulz-Hardt et } \\
\text { al., 2009; Staw, } \\
\text { 1997) }\end{array}$ \\
\hline & $\begin{array}{l}\text { Objective measures: } \\
\text { 1) Number of years a family business is making losses: } \\
\text { 2) Degree of financial distress (Altman Z-score). } \\
\text { Following Altman (1968, 1983) and subsequent } \\
\text { literature, the following variables and notations can } \\
\text { be used to measure the Altman Z-Score in public } \\
\text { firms = A*3.3 + B*.99 + } \mathrm{C}^{*} .6+\mathrm{D}^{*} 1.2+\mathrm{E}^{*} 1.4^{1} \text { : } \\
\text { - } \\
\text { Healthy firms are those with an Altman Z-score } \\
\text { higher than } 2.99 \text { (safe zone) } \\
\text { Firms with a moderate probability of distress are } \\
\text { those with an Altman Z-score between } 1.81 \text { and } 2.99 \\
\text { (gray zone) } \\
\text { Firms with a high probability of distress are those } \\
\text { with an Altman Z-score lower than 1.81 (distress } \\
\text { zone) } \\
\text { Alternative bankruptcy weighting factors should be used for } \\
\text { private firms (see Altman, 2000). }\end{array}$ & $\begin{array}{l}\text { (Altman, 1968; } \\
\text { 1983; Salvato } \\
\text { et al., 2010; } \\
\text { Schulz-Hardt et } \\
\text { al., 2009) }\end{array}$ \\
\hline
\end{tabular}

(R): Reverse-coded

private firms (see Altman, 2000).

${ }^{1} \mathrm{~A}=$ Earnings Before Interest \& Taxes/ Total Asset (measures productivity of firm assets); B = Net Sales/ Total Assets (sales-generating ability of firm assets); C = Book Value of Equity/ Total Liabilities (measures potential for insolvency); $\mathrm{D}$ = Working Capital/ Total Assets (measures net liquid assets relative to total capitalization); and $\mathrm{E}$ = Retained Earnings/ Total Assets (measures amount of reinvested earnings and/or losses in the firm). 